Jurnal Sulolipu : Media Komunikasi Sivitas Akademika dan Masyarakat

Vol. 19 No.2 2019

e-issn : 2622-6960, p-issn : 0854-624X

\title{
PEMANFAATAN SERBUK DAUN JAMBU BIJI (Psidium guajava L) DALAM MENURUNKAN KADAR TIMBAL (Pb) PADA AIR LIMBAH DI KAWASAN INDUSTRI MAKASSAR
}

*Muh.ikbal Arief, ${ }^{* *}$ Muhammad Kamil,

* Jurusan Kesehatan Lingkungan Poltekkes Kemenkes Makassar

** Jurusan Kesehatan Lingkungan Poltekkes Kemenkes Makassar

*) E-mail :mikbalarif@gmail.com/085398237919,

\begin{abstract}
The levels of lead $(\mathrm{Pb})$ is high in the wastewater would be detrimental to humans and the environment. Several methods for removing heavy metal from sewage water has done with the physical and chemical processes. Biomaterial daun guavas (Psidium guajava $L$ ) can be used as adsorbent can bind to heavy metals, this is because the content of tannin in the adsorbent. As for the purpose of this research is to know the ability of guava leaf powder (Psiduim guajava $\mathrm{L}$ ) to lower the levels of lead $(\mathrm{Pb})$ in the waste water industry taeniatus Makassar. This type of research is research that is quasi experiment i.e. knowing the ability of guava leaf powder (Psidium guajava $L$ ) in lowering levels of lead $(\mathrm{Pb})$ in waste water in industrial area of Makassar. From the results obtained that guava leaf powder testing (Psidium guajava L) in the waste water industry taeniatus Makassar with variation concentration, concentration to $150 \mathrm{gr}$ was able to decrease of $0.13 \mathrm{mg} / \mathrm{l}(14 \%)$, the concentration of $200 \mathrm{gr}$ were able to decrease of $0.26 \mathrm{mg} / \mathrm{l}(20 \%)$, the concentration of $250 \mathrm{gr}$ capable of lowering of $0.42 \mathrm{mg} / \mathrm{l}(54 \%)$. Conclusion of this research is that the testing of the powder leaves of guava (Psidium guajava $L$ ) capable of lowering the levels of lead $(P b)$ in the waste water industry taeniatus Makassar. Subsequent researchers need to pay attention to advice about the determination of the concentration and special treatment so that substances tannins contained in the powder can bound guava leaf.
\end{abstract}

Key words: waste water industrial area, guava leaves, Dust concentration, the levels of lead $(\mathrm{Pb})$ ABSTRAK

Kadar timbal $(\mathrm{Pb})$ yang tinggi dalam air limbah akan merugikan manusia dan lingkungan. Beberapa metode untuk menghilangkan logam berat dari air limbah telah dilakukan dengan proses fisika dan kimia. Biomaterial daun jambu biji (Psidium guajava $L$ ) dapat digunakan sebagai adsorben dapat mengikat logam berat, hal ini dikarenakan kandungan tanin dalam adsorben tersebut. Adapun tujuan penelitian ini adalah untuk mengetahui kemampuan serbuk daun jambu biji (Psidium guajava $L$ ) untuk menurunkan kadar timbal $(\mathrm{Pb})$ pada air limbah dikawasan industri Makassar. Jenis penelitian ini adalah penelitian yang bersifat eksperimen semu yaitu mengetahui kemampuan serbuk daun jambu biji (Psidium guajava $L$ ) dalam menurunkan kadar timbal $(\mathrm{Pb}$ ) pada air limbah di kawasan industri Makassar. Dari hasil penelitian yang diperoleh bahwa pengujian serbuk daun jambu biji (Psidium guajava L) pada air limbah dikawasan industri Makassar dengan variasi konsentrasi, untuk konsentrasi $150 \mathrm{gr}$ mampu menurunkan sebesar 0,13 mg/l (14\%), konsentrasi $200 \mathrm{gr}$ mampu menurunkan sebesar 0,26 mg/l (20\%), konsentrasi $250 \mathrm{gr}$ mampu menurunkan sebesar 0,42 mg/l (54\%) Kesimpulan penelitian ini adalah bahwa pengujian serbuk daun jambu biji (Psidium guajava $L$ ) mampu menurunkan kadar timbal $(\mathrm{Pb})$ pada air limbah dikawasan industri Makassar. Saran peneliti selanjutnya perlu memperhatikan tentang penentuan konsentrasi dan perlakuan khusus sehingga zat tanin yang terkandung pada serbuk daun jambu biji dapat terikat.

Kata Kunci $\quad$ : Air limbah kawasan industri, Serbuk daun jambu biji, konsentrasi, Kadar timbal $(\mathrm{Pb})$

\section{PENDAHULUAN}

Jumlah penduduk indonesia pada 2018 mencapai 265 juta jiwa. Jumlah tersebut terdiri dari 133,17 juta jiwa lakilaki dan 131,88 juta jiwa perempuan. Seiring dengan bertambahnya penduduk hal ini tentu berimbas kepada banyaknya kegiatan yang dilakukan dari berbagai macam sektor.Mulai dari kegiatan industri, perkantoran, pedagangan, pelayanan kesehatan dan pelayanan jasa.

Dari kegiatan tersebut tentu memberikan dampak bagi lingkungan salah satu diantaranya adalah terjadinya pencemaran lingkungan dari limbah yang dihasilkan dari kegiatan tersebutmasalah pencemaran lingkunganmenjadimasalahyangsangatkriti $s$ baginegaramaju maupun berkembang.Sehingga perlu dilakukan penyehatan dan pengelolaan terhadap lingkungan untuk keseimbangan ekosistem yang ada di dalamnya.

$\mathrm{Di}$ Indonesia kasus pencemaran timbal $(\mathrm{Pb})$ merupakan kasus yang sangat banyak di perbincangkan. Beberapa wilayah di indonesia mengalami pencemaran lingkungan oleh timbal $(\mathrm{Pb})$ seperti kasus tercemarnya sungai di Desa Cinangkan, Cimpae, Bogor, Jawa Barat 
Jurnal Sulolipu : Media Komunikasi Sivitas Akademika dan Masyarakat

Vol. 19 No.2 2019

e-issn : 2622-6960, p-issn : 0854-624X

pada tahun 2012, dimana jumlah timbal (Pb) mencapai $10.000 \mathrm{ppm}$ yang melebihi batas standar mutu dari WHO.

Beberapa metode untuk menghilangkan logam berat dari air limbah telah dilakukan dengan proses fisika dan kimia yang meliputi presipitasi, dan pertukaran ion. Tetapi metodemetode tersebut diatas masih mahal terutama bagi negara-negara yang sedang berkembang. Proses adsorpsi merupakan teknik permurnian dan pemisahan yang efektif dipakai dalam industri karena dianggap lebih ekonomis dalam pengolahan air limbah.

Kawasan industri merupakan bagian yang tak terpisahkan dengan kehidupan masyarakat di era yang maju saat ini semakin berkembangnya kawasan industri dalam suatu wilayah menunjukkan peningkatan kebutuhan masyarakat akan produk yang dihasilkan.

Jambu biji (Psidium guajava L) ditingkatkan pemanfaatnya sehingga memberikan nilai yang lebih tinggi. Salah satunya pemanfaatnya adalah sebagai adsorben dalam proses adsorpsi logam berat.(Wisnubroto,2002).

Pada daun, kulit batang dan daging buah jambu biji dapat ditemukan zat tanin.Zat tanin inilah yang berperan dalam penyerapan logam berat. Penelitian ini mengacu pada prinsip kerja yang sama dengan karbon aktif. Kandungan tanin pada kulit batang jambu biji lebih banyak dibandingkan pada daun. Pada kulit batang kadar tanin sebesar $12-30 \%$ sedangkan pada daun sebesar 11-17\% sehingga digunakan kulit batang sebagai adsorben dalam mengadsorpsi logam berat. Kandungan - kandungan yang terdapat dalam kulit batang jambu biji (Psidium guajava $L$ ) adalah $\mathrm{CaCo}_{3}$, tanin, dammar (Ticzon, 1997).

Hasil penelitian Pandia, Muhammad Ferdiyansyah dan Febri Maihendra (2017) menyatakan bahwa kulit batang jambu biji (Psidium guajava $L$ ) dapat mengikat logam berat Cu sebesar $69,1540 \%$ dan $\mathrm{Ni}$ sebesar $75,17 \%$ dalam limbah cair.

Dasar penelitian ini di peroleh dari penelitian Nanda leorita (2011), yang mana penelitian ini mengunakan daun jambu biji untuk menurunkan kadar

timbal. Daun jambu biji merupakan biomaterial yang efisien dan relatif murah untuk menyerap ion logam pada air sungai, dengan daya serap tertinggi pada logam timbal $(\mathrm{Pb})$ dengan penyerapan sebesar $45,657 \mathrm{ppm}(61,56 \%)$ selama 40 menit dengan konsentrasi 3 gram daun jambu biji.

Dari hasil penelitian tersebut peneliti tertarik untuk meningkatkan kadar absorben agar eksperimen ini lebih efektif.

\section{METODE}

Jenis penelitian yang dilakukan adalah penelitian yang bersifat eksperimen semu (Quasi eksperiment) yaitu mengetahui kemampuan serbuk daun jambu biji (Psidium guajava $L$ ) untuk menurunkan kadar timbal $(\mathrm{Pb})$ pada air limbah kawasan industri Makassar penelitian ini dilakukan dengan memberikan dosis serbuk daun jambu biji (Psidium guajava L) dimulai dari konsentrasi $150 \mathrm{gr}$, 200gr, 250gr.

Desain penelitian. Berdasarkan tujuan penelitian, yaitu mengetahui kemampuan daun jambu biji untuk menurunkan kadar timbal $(\mathrm{Pb})$ air limbah kawasan industri Makassar. Akan di paparkan atau di ujikan dengan waktu 40 menit dengan variasi dosis $150 \mathrm{gr}, 200 \mathrm{gr}$, $250 \mathrm{gr}$.

Waktu penelitian ini dibagi dua tahap yaitu.Tahap persiapan, Bulan Desember 2018 - Januari 2019. Tahap pelaksanan : Bulan April 2019 - Mei 2019.

Pengambilan sampel penelitian dilaksanakan di kawasan industri Makassar Wasten Water Treatment Plant (WWTP), Jln. Perintis kemerdekaan KM 15, Daya, kota Makassar. Sulawesi Selatan

\section{Jumlah dan cara pengambilan subjek}

Populasi dalam penelitian ini adalah semua air limbahinlet di instalasi pengolahan dikawasan industri Makassar.Sampel dalam penelitian ini adalah semua air limbah di kawasan industri Makassar.Metode pengambilan sampel yaitu menggunakan Grab Sampel (Teknik pengambilan sampel secara acak tanpa ada penyeleksian khusus) yang 
Jurnal Sulolipu : Media Komunikasi Sivitas Akademika dan Masyarakat

Vol. 19 No.2 2019

e-issn : 2622-6960, p-issn : 0854-624X

diambil langsung dari inlat Instalasi pengolahan air limbah kawasan industri Makassar.

\section{Jenis Dan Cara Pengumpulan Data}

Data primer adalah data yang diperoleh berdasarkan hasil pemeriksaan laboratorium kadar Timbal $(\mathrm{Pb})$. Data Sekunder diperoleh dari hasil penelusuran perpustakan berupa buku-buku, artikel, jurnal, hasil penelitian sebelumnya dan internet serta media informasi lainnya yang dianggap memiliki keterkaitan dengan penelitian ini.

Pengolahan dan analisis data

Pengolahan data pada penelitian ini dilakukan secara manual dengan menggunakan alat bantu komputer, kalkulator dan alat hitung lainnya. Analisis data yang digunakan adalah data yang telah diperoleh dari hasil pemeriksaan laboratorium dan analisa secara deskriktif dan diuraikan dalam bentuk tabel dan narasi selanjutnya dibuat suatu kesimpulan.

Hasil

Penelitian ini dilakukan dikawasan industri Makassar (PT.Kima) terletak dijalan Perintis Kemerdekaan KM. 15 Daya Makassar, Sulawesi selatan.

1. Hasil pemeriksaan air limbah kawasan industri Makassar tahun 2019 untuk mengetahui kadar timbal (Pb)

Tabel 1

Kadar timbal $(\mathrm{Pb})$ pada air limbah kawasan industri Makassar Tahun 2019

\begin{tabular}{ccc}
\hline No & $\begin{array}{c}\text { Pemeriksaan } \\
\text { kadar timbal } \mathrm{Pb}\end{array}$ & $\begin{array}{c}\text { Hasil kadar } \\
\text { timbal }(\mathrm{Pb})\end{array}$ \\
\cline { 3 - 3 } & Awal & 0,58
\end{tabular}

\begin{tabular}{ccc}
\hline 2 & $\begin{array}{c}\text { Setelah } \\
\text { penambahan } \mathrm{Pb}\end{array}$ & 0,92 \\
\hline
\end{tabular}

Pemeriksaan awal sampel air limbah kawasan industri Makassar yang terletak di jalan Perintis Kemerdekaan KM.15, Daya, Kec. Biringkanaya, Kota Makassar, Sulawesi Selatan. Yang diambil langsung di inlet Wasten Water Treatment Plant (WWTP) instalasi pengolahan air limbah

kawasan industri Makassar, untuk melihat kadar timbal $(\mathrm{Pb})$ yang di mana hasilnya diperoleh dari pemeriksaan di Balai Pengkajian Teknologi Pertanian Sulawesi Selatan, Laboratorium tanah JI. DR. Ratulangi, Allepolea, Lau, Kabupaten Maros, Sulawesi Selatan dengan hasil yang diperoleh yaitu $0,58 \mathrm{mg} / \mathrm{l}$.

Hasil tersebut dibawah baku mutu air limbah kegiatan kawasan industri. Namun dengan kadar timbal $(\mathrm{Pb}) 0,58 \mathrm{mg} / \mathrm{l}$, sulit untuk melihat tingkat penurunan kadar timbal $(\mathrm{Pb})$ yang dilakukan oleh serbuk daun jambu biji (Psidium guajava $L$ ) karena hasilnya akan minus (-) atau memiliki lambang $\left(^{*}\right)$ saat pengukuran, maka peneliti menambahkan larutan $\mathrm{Pb}$ pada sampel air limbah kawasan industri Makassar dengan tujuan untuk meningkatkan kadar timbal $(\mathrm{Pb})$ pada sampel air limbah kawasan industri Makassar tersebut dengan hasil kadar timbal $(\mathrm{Pb})$ setelah di tambahkan larutan $\mathrm{Pb}$ sebesar 0,92 mg/l.

\section{Hasil penelitian rata-rata penurunan kadar timbal $(\mathrm{Pb})$ pada konsentrasi 150gr, 200gr, 250gr.}

Penambahan serbuk daun jambu biji (Psidium guajava L) pada air limbah di kawasan industri Makassar setelah penambahan larutan $\mathrm{Pb}$ dapat dilihat dibawah

Tabel 2

Rata-rata penurunan Kadar timbal $(\mathrm{Pb})$ pada air limbah di kawasan industri Makassar dengan konsentrasi $150 \mathrm{gr}$, 200gr, 250gr. Serbuk daun jambu biji (Psidium guajava $L$ ) dengan waktu 40 menit

\begin{tabular}{ccccc}
\hline $\mathbf{N}$ & Konse & Sebe & Penur & Rata- \\
O & ntrasi & $\begin{array}{c}\text { lum } \\
\text { perla } \\
\text { kuan }\end{array}$ & unan & $\begin{array}{c}\text { rata } \\
\text { penur } \\
\text { unan }\end{array}$ \\
& & & & \\
& & &
\end{tabular}

\begin{tabular}{|c|c|c|c|c|c|c|}
\hline & & & $\begin{array}{l}(\mathbf{m} \\
\mathbf{g} / \mathrm{l})\end{array}$ & $(\mathrm{mg} / \mathrm{l})$ & $\begin{array}{l}\text { (m } \\
\text { g/l) }\end{array}$ & \\
\hline & (gr) & (mg/l & 1 & II & III & $(\mathrm{mg} / \mathrm{l})$ \\
\hline 1 & 150 & o,92 & $\begin{array}{c}0,1 \\
3\end{array}$ & 0,14 & $\begin{array}{c}0,1 \\
2\end{array}$ & 0,13 \\
\hline 2 & 200 & 0,92 & $\begin{array}{c}0,2 \\
8\end{array}$ & 0,26 & $\begin{array}{c}0,2 \\
5\end{array}$ & 0,26 \\
\hline 3 & 250 & 0,92 & $\begin{array}{c}0,4 \\
3\end{array}$ & 0,41 & $\begin{array}{c}0,4 \\
4\end{array}$ & 0,42 \\
\hline
\end{tabular}


Jurnal Sulolipu : Media Komunikasi Sivitas Akademika dan Masyarakat

Vol. 19 No.2 2019

e-issn : 2622-6960, p-issn : 0854-624X

Tabel 2 diatas merupakan hasil ratarata penurunan kadar timbal $(\mathrm{Pb})$ sebelum dan sesudah perlakuan dengan serbuk daun jambu biji (Psidium guajava $L$ ) yang di gunakan pada air limbah dikawasan industri Makassar, dari pengulangan pertama hingga pengulangan ketiga. Hasil untuk kadar timbal $(\mathrm{Pb})$ pada sampel air limbah dikawasan industri Makassar sebelum perlakuan yaitu dengan rata-rata $0,92 \mathrm{mg} / \mathrm{l}$.

Adapun hasil konsentrasi penurunan dari pengulangan pertama hingga pengulangan ketiga, untuk konsentrasi 150 gr mampu menurunkan kadar timbal $(\mathrm{Pb})$ dengan menambahkan serbuk daun jambu biji (Psidium guajava L) pada air limbah dikawasan industri Makassar yaitu dengan rata-rata penurunan $0,13 \mathrm{mg} / \mathrm{l}$. Adapun hasil konsentrasi penurunan dari pengulangan pertama hingga pengulangan ketiga, untuk konsentrasi 200 gr mampu menurunkan kadar timbal $(\mathrm{Pb})$ dengan menambahkan serbuk daun jambu biji (Psidium guajava L) pada air limbah dikawasan industri Makassar yaitu dengan rata-rata penurunan $0,26 \mathrm{mg} / \mathrm{l}$.

Adapun hasil konsentrasi penurunan dari pengulangan pertama hingga pengulangan ketiga, untuk konsentrasi 200 gr mampu menurunkan kadar timbal $(\mathrm{Pb})$ dengan menambahkan serbuk daun jambu biji (Psidium guajava L) pada air limbah dikawasan industri Makassar yaitu dengan rata-rata penurunan $0,26 \mathrm{mg} / \mathrm{l}$.

3. Hasil persentase rata-rata penurunan kadar timbal $(\mathrm{Pb})$ pada air limbah dikawasann industri Makassar dengan konsentrasi 150gr, 200gr, 250gr. Serbuk daun jambu biji (Psidium guajava $L$ ) dapat dilihat pada grafik di bawah ini : 
Jurnal Sulolipu : Media Komunikasi Sivitas Akademika dan Masyarakat

Vol. 19 No.2 2019

e-issn : 2622-6960, p-issn : 0854-624X

industri Makassar, sehingga hasil yang didapat setelah penambahan larutan $\mathrm{Pb}$ yaitu: $0,92 \mathrm{mg} / \mathrm{l}$.

Waktu pada penelitian ini di ambil dari penelitian sebelumnya yang di lakukan oleh Nanda Leorita (2011), menemukan waktu pengurangan timbal ataupun penyerapan timbal $(\mathrm{Pb})$ yang tertinggi untuk $1 \mathrm{gr}$ dan $2 \mathrm{gr}$ dalam waktu 20 menit dan $3 \mathrm{gr}$ dalam waktu 40 menit. Sehingga peneliti mengambil waktu yang sama dari peneliti sebelumnya dengan waktu 40 menit.

Penambahan serbuk daun jambu biji (Psidium guajava $L$ ) pada air limbah dikawasan industri Makassar dengan variasi konsentrasi yang telah di tentukan dapat di uraikan dengan hasil yaitu

1. Hasil Rata-rata penurunan kadar timbal (Pb) pada air limbah dikawasan industri Makassar setelah penambahan serbuk daun jambu biji (Psidium guajava L) dengan variasi konsentrasi 150gr,200gr,250gr dengan waktu 40 menit.

Hal ini sejalan dengan penelitian Nanda Leorita (2011) menggunakan serbuk daun jambu biji (Psidium guajava L) dengan konsentrasi sebanyak 1gr, 2gr, 3gr, selama 40 menit. Dengan penyerapan tertinggi pada logam timbal $(\mathrm{Pb})$ terjadi pada konsentrasi 3gr dengan penyerapan sebesar 45,657 ppm $(81,54 \%)$ selama 40 menit,

Dari hasil percobaan yang dilakukan dari pengulangan pertama hingga pengulangan ketiga. Bahwa penambahan serbuk daun jambu biji (Psidium guajava L) dengan konsentrasi $150 \mathrm{gr}$ selama 40 menit memperoleh hasil dengan rata-rata penurunan sebesar $0,13 \mathrm{mg} / \mathrm{l}$. dan hasil penambahan serbuk daun jambu biji (Psidium guajava L) dengan konsentrasi 200 grselama 40 menit memperoleh hasil dengan rata-rata penurunan sebesar $0,26 \mathrm{mg} / \mathrm{l}$. sedangkan untuk hasil penambahan serbuk daun jambu biji (Psidium guajava L) selama 40 menit

memperoleh hasil dengan rata-rata penurunan sebesar $0,42 \mathrm{mg} / \mathrm{l}$.

$$
\text { Hasil dari ketiga variasi }
$$

konsentrasi tersebut mampu menurunkan kadar timbal (Pb) mengunakan serbuk daun jambu biji (Psidium guajava $L$ ) pada sampel air limbah dikawasan industri Makassar. Penyerapan kadar timbal $(\mathrm{Pb})$ pada air limbah di kawasan industri Makassar menggunakan serbuk daun jambu biji (Psidium guajava $L$ ) terjadi karena logam $\mathrm{Pb}$ merupakan logam berat yang sangat reaktif, selain itu logam berat mempunyai sifat yang mudah mengikat bahan organik dan mengendap.

Biomaterial daun jambu biji (Psidium guajava $L$ ) yang dii gunakan sebagai adsorben dapat mengikat logam berat, hal ini dikarenakan kandungan tanin dalam adsorben tersebut.Zat tanin inilah yang berperan dalam penyerapan logam berat. Penelitian ini mengacu pada prinsip kerja yang sama dengan karbon aktif. Kandungan tanin pada daun jambu biji kadar tannin sebesar $11-17 \%$.

Dari ketiga variasi konsentrasi serbuk daun jambu biji (Psidium guajava L) tersebut mampu menurunkan kadar timbal $(\mathrm{Pb})$ pada air limbah dikawasan industri Makassar, penurunan terbesar dari ketiga variasi konsentrasi tersebut yaitu terjadi pada konsentrasi $250 \mathrm{gr}$ sebesar $0,42 \mathrm{mg} / \mathrm{l}$. Hal ini sejalan dengan penelitian sebelumnya yang dilakukan oleh Nanda Leorita (2011) yaitu penyerapan logam timbal $(\mathrm{Pb})$ untuk konsentrasi 1gr, 2gr, 3gr. Yang paling banyak menyerap terjadi terjadi pada konsentrasi $3 \mathrm{gr}$ dengan penyerapan sebesar 45,657 ppm $(81,54 \%)$ selama 40 menit, meskipun tidak besar penurunan yang terjadi pada penelitian sebelumnya.

2. Hasil persentase rata-rata penurunan kadar timbal (Pb) dengan penambahan serbuk daun jambu biji (Psidium guajava $L$ ) pada air limbah di kawasan industri Makassar dengan waktu 40 menit 
Jurnal Sulolipu : Media Komunikasi Sivitas Akademika dan Masyarakat

Vol. 19 No.2 2019

e-issn : 2622-6960, p-issn : 0854-624X

Hal ini sejalan dengan
penelitian Nanda Leorita

menggunakan serbuk daun jambu biji

(Psidium guajava L)dengan

konsentrasi sebanyak 1gr, 2gr, 3gr, selama 40 menit. Dengan penyerapan tertinggi pada logam timbal $(\mathrm{Pb})$ terjadi pada konsentrasi 3gr dengan penyerapan sebesar 45,657 ppm $(81,54 \%)$ selama 40 menit,

Dari hasil percobaan yang dilakukan dari pengulangan pertama hingga pengulangan ketiga. Sebelum penambahan yaitu $0,92 \mathrm{mg} / \mathrm{l}$. Hasil persentase rata-rata penurunan kadar timbal $(\mathrm{Pb})$ dengan penambahan serbuk daun jambu biji (Psisdium guajava $L$ ) pada air limbah dikawasan industri Makassar.

Konsentrasi $150 \mathrm{gr}$ dengan rata-rata penurunan kadar timbal $(\mathrm{Pb})$ yang terjadi pada air limbah kawasan industri Makassar setelah penambahan serbuk daun jambu biji (Psidium guajava $L$ ) dengan rata-rata $0,13 \mathrm{mg} / \mathrm{l}$ dengan persentase $14 \%$ hasil tersebut merupakan hasil yang terkecil untuk penurunan kadar timbal $(\mathrm{Pb})$ pada air limbah di kawasan industri Makassar. Untuk konsentrasi $200 \mathrm{gr}$ dengan rata-rata penurunan kadar timbal $(\mathrm{Pb})$ yang terjadi pada air limbah dikawasan industri Makassar setelah penambahan serbuk daun jambu biji (Psidium guajava $L$ ) dengan rata-rata $0,26 \mathrm{mg} / \mathrm{l}$ dengan persentase $(20 \%)$. Sedangkan untuk konsentrasi 250 gr degan rata-rata penurunan kadar timbal $(\mathrm{Pb})$ yang terjadi pada air limbah dikawasan industri Makassar setelah penambahan serbuk daun jambu biji (Psidium guajava $L$ ) dengan rata-rata $0,42 \mathrm{mg} / \mathrm{l}$ dengan persentase (54\%). Konsentrasi 250gr merupakan konsentrasi yang paling banyak menurunkan kadar timbal $(\mathrm{Pb})$ pada air limbah di kawasan industri Makassar. Hal ini sejalan dari penelitian sebelumnya yang di lakukan oleh Nanda Leorita (2011) dengan kesimpulan yang dilakukan oleh penelitian sebelumnya yaitu semakin banyak serbuk yang

digunakan semakin banyak pula penurunan yang terjadi.Meskipun tidak terlalu banyak penurunan yang terjadi dari penelitian sebelumnya karena terjadi kesalahan pada saat penentuan konsentrasi yang digunakan sehingga penurunan yang terjadi tidak terlalu besar.

\section{Kesimpulan}

Berdasarkan hasil penelitian mengenai serbuk daun jambu biji (Psidium quajava $\mathrm{L})$ dalam menurunkan kadar timbal $(\mathrm{Pb})$ pada air limbah kawasan industri Makassar dapat diambil kesimpulan

1. Penambahan serbuk daun jambu biji (Psidium guajava $L$ ) pada air limbah dikawasan industri Makassar dengan konsentrasi $150 \mathrm{gr}$ mampu menurunkan kadar timbal $(\mathrm{Pb})$ ratarata penurunan $0,13 \mathrm{mg} / \mathrm{l}$ dengan persentase (14\%)meskipun tidak terlalu efisien penurunannya.

2. Penambahan serbuk daun jambu biji (Psidium guajava L) pada air limbah dikawasan industri Makassar dengan konsentrasi $200 \mathrm{gr}$ mampu menurunkan kadar timbal $(\mathrm{Pb})$ ratarata penurunan $0,26 \mathrm{mg} / \mathrm{l}$ dengan persentase ( $20 \%$ )

3. Penambahan daun jambu biji (Pisidium quajava L) pada air limbah dikawasan industri Makassar dengan konsentrasi $250 \mathrm{gr}$ mampu menurunkan kadar timbal $(\mathrm{Pb})$ ratarata penurunan $0,42 \mathrm{mg} / \mathrm{l}$ dengan persentase (54\%).

\section{Saran}

Penelitian ini menambahkan larutan $\mathrm{Pb}$ pada air sampel limbah karena kadar pb dikawasan industri Makassar memenuhi syarat kadar timbal $(\mathrm{Pb})$ oleh itu pada penelitian selanjutnya diharapkan dapat mencari air limbah yang kadar $\mathrm{Pb}$ nya lebih tinggi dari hasil penelitian ini sehingga adsorben dapat di gunakan lebih efektif 
Jurnal Sulolipu : Media Komunikasi Sivitas Akademika dan Masyarakat

Vol. 19 No.2 2019

e-issn : 2622-6960, p-issn : 0854-624X

\section{DAFTAR PUSTAKA}

Abdul Rahman Arif. 2014. Adsorpsi Karbon Aktif Dari Tempurung Kluwak (Pangium Edule) Terhadap Penurunan Fenol.Skripsi.Fakultas sains dan teknologi. Universitas Negeri Alauddin Makassar (Online) http://repositori.uin-alauddin.ac.id/ Diakses 12 April 2019

Sjamsul Arifin Ahmad, dkk.2011. Ilmu Kimia Dan Kegunaan Tumbuh-Tumbuhan Dan Obat. Indonesia 1 (Online) http://books.google.co.id/ Di akases 13 Desember 2019

Umar Fahmi Ahmadi. 2011. Dasar-Dasar Penyakit Berbasis Lingkungan. Jakarta: Raja Grafindo IImu

Ali M, dkk. 2010. Kemampuan Tanaman Magrove Untuk Menyerap Logam Berat Merkuri $(\mathrm{Hg})$ Dan Timbal $(\mathrm{Pb})$. Jurnal teknik sipil dan perencanaan universitas pembangunan nasional veteran 6(2): (Online) https://ejournals3.undip.ac.id/ diaksess 23 desember 2018

Berdasarkan Proyeksi Badan Perencanaan Pembangunan Nasional (BAPPN). 2018. Jumlah penduduk indonesia tahun 2018. (online) http://www.databoks.katadata.co.id diakses 29 Desember 2018

Cahyono, Bambang. 2010. Sukses Budidaya Jambu Biji Di Pekarangan Dan Perkebunan.Yogyakarta : Lily Publisher

Darmono. 2001. Lingkungan Hidup Dan Pencemaran. Jakarta: Universitas Indonesia Press

Effendi, Hefni.2003. Telaah Kualitas Air Bagi Pengolahan Sumberdaya Dan Lingkungan Perairan.Yogyakarta : Kanisius

Irianti T. Tanti et al. 2017. Logam Berat \& Kesehatan. Yogyakarta: Grafika Indah.

Nanda Leorita. 2011. Uji Daya Serap Ion Logam Berat Cr Dan Cu Dari Air Sungai Mengunakan Biomaterial Daun Jambu Biji Dengan Metode Spektrofotometri Serapan Ataom (SSA).Skripsi.Fakultas Tarbiyah Dan Keguruan Universitas Islam Negeri Sultan Syarif Kasium. Riau (Online) http://repository.uin-suska.ac.id/ Diakses 29 Desember 2018

Lu, Frank C.1994. Toksikologi Dasar Asas Organ Sasaran, Dan Penilian Risiko. Jakarta: Universitas Indonesia press

Misda Fauici. 2017. Adsorpsi Ion Pb (II) Dan Cr (IV) Mengunakan Arang Kulit Pisang Kepok (Musca Paradisiaca Linn) Pada Limbah Cair Industry (Studi Kasus Pt. Sermani Steel).Sripsi. PS Pengolahan lingkungan hidup. Pasca Sarjana. Universitas Hasanuddin (Online) https://digilib.unhas.ac.id/ Diakses 25 Desember 2018.

National.goegrapic. 2012. Pencemaran Timbal Di Bogor Ditangani KLH. (online) http://nationalgeographic.grid.id. Diakses 3 januari 2019

Naria. E., 2012.Mewaspadai Dampak pencemaran Timbal (Pb) Di Lingkungan Terhadap Kesehatan.Jurnal komunikasi penelitian. 17 (4) :124-130. (online) http://repository.usu.ac.id. Diakses 15 Januari 2019

Pandia S., Muhammad Ferdiyansyah, dan Febri Maihendra. 2017. Pembuatan Adsorben Dari Kulit Batang Jambu Biji (Psidium Guajava L) Untuk Menyerap Logam Tembaga (Cu) Dan Nikel (Ni) Pada Limbah Cair Industri Pelapisan Logam. Jurnal teknik kimia USU. Vol.6 No. 4 : 34-40. (online) https://jurnal.usu.ac.id. Diakses 20 Desember 2018 
Jurnal Sulolipu : Media Komunikasi Sivitas Akademika dan Masyarakat

Vol. 19 No.2 2019

e-issn : 2622-6960, p-issn : 0854-624X

Palar.H., 2008. Pencemaran Dan Toksikologi Logam Berat. Jakarta : PT. Rineka Cipta

Rohian Yahya. 2018. Pengolahan Limbah Kromium Industry Electroplating Menggunakan Teknologi Filtrasi, Absorbsi, Adsorpsi, Sedimentasi (FAAS).Skripsi. PS Fisika fakultas matematika dan ilmu pengetahuan alam. Universitas negeri Yogyakarta (Online) http://eprints.uny.ac.id/ Diakses 14 Mei 2019

Ronny. 2017. Dasar-Dasar Kesehatan Lingkungan. Makassar. Jurusan Kesehatan Lingkungan Politeknik Kesehatan Makassar

Rahim, dkk. 2017. Instalasi Pengolahan Air Limbah PT. KIMA. (online) http://www.scrid.com diakses 11 januari 2018

Sihombing. 2018. Efektivitas Serbuk Kulit Batang Jambu Biji (Psidium Gujava L) Dalam Menurunkan Air Sungai Belawan Di Desa Tanjung Gusta Kecamatan Sunggal Kabupaten Deli Serdang.Skripsi.Fakultas Kesehatan Masyarakat. Universitas Sumatera Barat. (Online) http:eprints.usb.ac.id/ Diakses 20 Desember 2018

Sugiharto. 2014. Dasar-Dasar Pengelolaan Air Limbah. Jakarta: Universitas Indonesia

Sartono. 2001. Racun Dan Keracunan. Jakarta: Widya Mestika

Wayan Budiyasa Suyasa, W.B. 2015. Pencemaran Air Dan Pengolahan Air Limbah.Bali: Udayana University Press

Widowati, dkk. 2008. Efek Toksik Logam. Yogyakarta: Andi Offset 